NOTE

\title{
Widespread survey finds no evidence of Haplosporidium nelsoni (MSX) in Gulf of Mexico oysters
}

\author{
Susan E. Ford ${ }^{1, *}$, Jenny Paterno ${ }^{1}$, Emily Scarpa1 ${ }^{1}$, Nancy A. Stokes ${ }^{2}$, Yungkul Kim ${ }^{1,3}$, \\ Eric N. Powell ${ }^{1}$, David Bushek ${ }^{1}$
}

\author{
${ }^{1}$ Haskin Shellfish Research Laboratory, Rutgers University, Port Norris, New Jersey 08349, USA \\ ${ }^{2}$ Virginia Institute of Marine Science, College of William and Mary, Gloucester Point, Virginia 23062, USA \\ ${ }^{3}$ Department of Biology, Jackson State University, Jackson, Mississippi 39217, USA
}

\begin{abstract}
The advent of molecular detection assays has provided a set of very sensitive tools for the detection of pathogens in marine organisms, but it has also raised problems of how to interpret positive signals that are not accompanied by visual confirmation. PCR-positive results have recently been reported for Haplosporidium nelsoni (MSX), a pathogen of the oyster Crassostrea virginica in 31 of 40 oysters from 6 sites in the Gulf of Mexico and the Caribbean Sea. Histological confirmation of the PCR results was not undertaken, and no haplosporidian has been reported from the numerous histological studies and surveys of oysters in the region. To further investigate the possibility that H. nelsoni is present in this region, we sampled 210 oysters from 40 sites around the Gulf of Mexico and Puerto Rico using PCR and 180 of these using tissue-section histology also. None of the oysters showed evidence of $H$. nelsoni by PCR or of any haplosporidian by histology. We cannot, therefore, confirm that $H$. nelsoni is present and widespread in the Gulf of Mexico and the Caribbean Sea. Our results do not prove that $H$. nelsoni is absent from the region, but taken together with results from previous histological surveys, they suggest that for the purposes of controlling oyster importation, the region should continue to be considered free of the parasite.
\end{abstract}

KEY WORDS: PCR · Oyster · Crassostrea virginica - Molecular detection · Infection · Shellfish importation · Haplosporidian

\section{INTRODUCTION}

The advent of molecular detection assays has provided a set of very sensitive tools for the detection of pathogens in marine organisms and their environment, but it has also raised questions of how to interpret positive signals that are not accompanied by visual confirmation using histological, cytological, or culture methods (Burreson 2008). The possibility of false positives with the use of polymerase chain reaction (PCR) technology for disease diagnosis can occur from laboratory contamination, the presence of non-infective or non- viable target cells, cross-reaction of the primers with DNA of other organisms, and from misinterpretation of PCR results. A recent paper reported PCR results of analyzing oysters from the Gulf of Mexico and the Caribbean Sea for the pathogen Haplosporidium nelsoni, which causes MSX (multinucleated sphere with unknown affinity) disease in the eastern oyster Crassostrea virginica (Ulrich et al. 2007). Of the 40 individuals assayed, 31, representing all 6 sampled locations, gave positive signals. The results were entirely unexpected. Plasmodial stages of what is presumed to be $H$. nelsoni have been detected in histological sections of 
C. virginica from Nova Scotia, Canada, to Biscayne Bay, Florida, USA (Haskin \& Andrews 1988, Barber et al. 1997, Stephenson et al. 2003), but none of the several histological studies of oysters in the Gulf of Mexico have reported $H$. nelsoni or any other haplosporidian (Couch 1985, Gauthier et al. 1990, Fisher et al. 1996, 2000, Kim et al. 1998, Winstead et al. 2004, Kim \& Powell 2006). The most comprehensive of these is the annual status and trends (S\&T) program (http:// ccma.nos.noaa.gov/about/coast/nsandt/welcome. html), which includes histological examination of approximately 200 oysters annually (1995 to present) from among 82 sites in the Gulf of Mexico from Texas to Florida, USA, and Puerto Rico (Kim \& Powell 2006). The Haskin Shellfish Research Laboratory (HSRL) of Rutgers University has performed histopathological examinations of Gulf of Mexico oysters for the S\&T program since 1995. To further investigate the possible presence of $H$. nelsoni in the Gulf of Mexico, we took advantage of the samples collected in this program by adding a PCR assay to the routine histological examination of C. virginica.

\section{MATERIALS AND METHODS}

Crassostrea virginica were collected between December 2007 and February 2008 at 32 sites representing 14 bay systems from lower Laguna Madre, Texas, to Florida Bay, Florida, USA, and C. rhizophorae were collected from 2 bays in Puerto Rico (Fig. 1, Table 1). In May and July 2010, C. virginica were sampled from 6 additional sites, representing 2 bay systems in Texas and 1 in Florida (Fig. 1, Table 1). All samples were express shipped directly to HSRL. Upon receipt, 12 oysters from each sample were opened using a shucking knife, which was rinsed in $10 \%$ bleach between each oyster. A section of gill about $4 \mathrm{~mm}$ wide and encompassing all 4 demibranchs approximately 6 to $7 \mathrm{~mm}$ posterior to the gill-palp junction was excised and preserved in $70 \%$ ethanol (EtOH) for PCR analysis. Dissecting instruments were scraped clean in a bleach-sand mixture, dipped in EtOH and flamed between each oyster. Between the PCR section and the palps, and adjacent to the piece of gill taken for PCR, a $5 \mathrm{~mm}$ section that included the mantle, gill, and visceral mass was removed and placed in a labeled cassette in Davidson's fixative. The first 5 of the 12 oysters were subsequently sectioned, stained, and examined for parasites and pathological conditions (Kim \& Powell 2007). Each EtOH-fixed gill sample from the same 5 oysters was individually minced and thoroughly mixed to maximize the representation of different portions of the gill in the sample taken for PCR analysis. Dissecting instruments were cleaned as above. The samples from Texas and Florida collected in 2010 were processed for PCR only, and those from the 2 Florida sites consisted of 10, rather than 5, oysters each. DNA was extracted from approximately $20 \mathrm{mg}$ of the minced tissue from each oyster using a Qiagen DNeasy Blood \& Tissue Kit according to the manufacturer's directions. A total of 210 oysters were analyzed individually by PCR, and 180 of these were examined histologically.

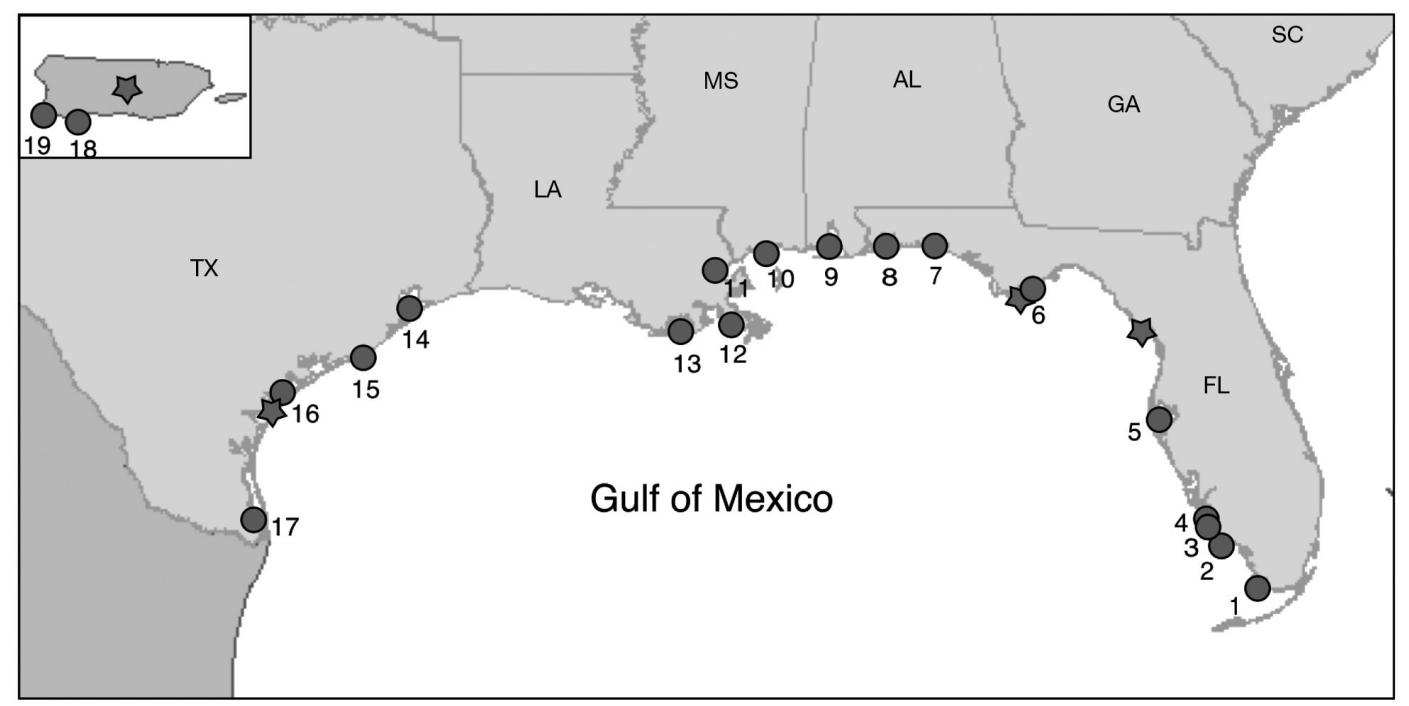

Fig. 1. Haplosporidium nelsoni. Map showing bay systems around the United States portion of the Gulf of Mexico, and Puerto Rico, where oyster samples were collected for histological and PCR detection of $H$. nelsoni. Circles represent locations sampled in the present study. Stars are those sampled by Ulrich et al. (2007). The star on Puerto Rico (inset) does not represent a specific location. See Table 1 for names of bay systems and number of sites sampled within each system 
Table 1. Haplosporidium nelsoni. Bay systems around the United States portion of the Gulf of Mexico, and Puerto Rico (PR), where oysters were collected for histological and PCR analysis to detect $H$. nelsoni. Five oysters from each site within a bay system were individually analyzed, except for Apalachicola Bay, where 10 oysters from each site were individually analyzed. Map numbers refer to Fig. 1

\begin{tabular}{|llll|}
\hline Map no. & Collection period & Bay system & No. of sites \\
\hline 1 & Feb 2008 & Florida Bay, FL & 2 \\
2 & Feb 2008 & Everglades, FL & 1 \\
3 & Feb 2008 & Rookery Bay, FL & 1 \\
4 & Feb 2008 & Naples Bay, FL & 1 \\
5 & Feb 2008 & Tampa Bay, FL & 7 \\
6 & Jul 2010 & Apalachicola Bay, FL & 2 \\
7 & Jan 2008 & Choctawhatchee Bay, FL & 3 \\
8 & Jan 2008 & Pensacola Bay, FL & 2 \\
9 & Jan 2008 & Mobile Bay, AL & 2 \\
10 & Jan 2008 & Mississippi Sound, MS & 3 \\
11 & Jan 2008 & Lake Borgne, LA & 2 \\
12 & Jan 2008 & Breton Sound, LA & 2 \\
13 & Jan 2008 & Terrebonne Bay, LA & 1 \\
14 & May 2010 & Galveston Bay, TX & 3 \\
15 & May 2010 & Brazos River, TX & 1 \\
16 & Dec 2007 & Espiritu Santo, TX & 2 \\
17 & Dec 2007 & Lower Laguna Madre, TX & 3 \\
18 & Feb 2008 & Bahia Montalva, PR & 1 \\
19 & Feb 2008 & Bahia de Boqueron, PR & 1 \\
\hline
\end{tabular}

Extracted DNA $(1 \mu \mathrm{l})$ was added to a master mix consisting of $2.5 \mu \mathrm{l}$ of $10 \times$ PCR Buffer II (Applied Biosystems), $1.5 \mu \mathrm{MgCl}_{2}(1.5 \mathrm{mM}$ final concentration), dNTPs (200 $\mu \mathrm{M}$ each), $25 \mathrm{pmol}$ each of the primers, $0.6 \mathrm{U}$ of AmpliTaq DNA polymerase, and enough nuclease-free water for a $25 \mu$ l total reaction volume. Cycling parameters were $2 \mathrm{~min}$ at $94^{\circ} \mathrm{C}$ for initial denaturation, then 35 cycles at $94^{\circ} \mathrm{C}$ for $30 \mathrm{~s}, 59^{\circ} \mathrm{C}$ for $30 \mathrm{~s}$, and $72^{\circ} \mathrm{C}$ for $1.5 \mathrm{~min}$ for the denaturation, annealing, and extension steps, respectively, and a final elongation at $72^{\circ} \mathrm{C}$ for 5 min (Renault et al. 2000). A total of $10 \mu \mathrm{l}$ of the amplification product were applied to a $2 \%$ agarose gel using SYBR Green ( $5 \mu \mathrm{l}$ in $40 \mathrm{ml}$ of gel buffer, $\mathrm{pH}$ 8.0) to stain the product, which was then photo-documented as a digital image. Positive and negative controls were included in each PCR run and consisted of $24 \mu \mathrm{l}$ of master mix with $1 \mu \mathrm{l}$ of DNA extract from a Haplosporidium nelsoniinfected oyster or $1 \mu$ l of nuclease-free water, respectively.

The concentration of DNA in 20 randomly selected samples was determined using a GeneQuant Pro (Amersham Biosciences) spectrophotometer. Concentrations ranged from 58 to $225 \mathrm{ng} \mathrm{ll}^{-1}$ and averaged $121 \mathrm{ng} \mathrm{\mu l}^{-1}$. DNA purity in the samples, assessed by the ratio of absorbance readings at 260 versus $280 \mathrm{~nm}$, was between 1.8 and 2.0. DNA quality was also assessed by electrophoresing total DNA from an additional 21 oysters (every tenth one) on a $2 \%$ agarose gel. The resulting bands were tight and had a molecular weight of approximately 2000 bp, indicating high-quality DNA.

The PCR assay for detection of genomic DNA from Haplosporidium nelsoni was modified from that published by Stokes et al. (1995) using the primers MSX A' (5'-CGA CTT TGG CAT TAG GTT TCA GAC C-3') and MSX B (5' -ATG TGT TGG TGA CGC TAA CCG-3'). Primer MSX A' is the same as MSX A originally designed by Stokes et al. (1995) and used by Ulrich et al. (2007), but has an extra 8 bases on the 5 '-end and amplifies a $573 \mathrm{bp}$, rather than a $564 \mathrm{bp}$, section of the same region of the small subunit (SSU) rDNA (Renault et al. 2000). Primer MSX A is much shorter than MSX B, resulting in a melting temperature $\left(T_{\mathrm{m}}\right)$ difference of $16.3^{\circ} \mathrm{C}$. By increasing the number of bases at the $5^{\prime}$-end of primer MSX A, the $T_{\mathrm{m}}$ difference was decreased to $4.2^{\circ} \mathrm{C}$. Using primer MSX A', rather than MSX A, along with MSX B allowed the annealing temperature during PCR cycling to be increased from 50 to $59^{\circ} \mathrm{C}$, thus increasing PCR stringency while maintaining specificity for $H$. nelsoni.
The 564 bp MSX A + MSX B amplification product encompasses a conserved region of about 220 bases of the SSU rDNA (bases 291 to 511 of the product). This conserved region from Haplosporidium nelsoni (GenBank Accession U19538) was aligned with that of the host, Crassostrea virginica (X60315), and another oyster pathogen, H. costale (AF387122), using ClustalW in MacVector 8.0. We also performed a BLAST search (Altschul et al. 1997) using this region of $H$. nelsoni.

\section{RESULTS}

None of the 210 oysters Crassostrea virginica subjected to the PCR assay showed any bands on the gels, whereas the positive control consistently showed the expected band. Histological examination of 180 of the same oysters revealed that they were parasitized by a variety of organisms, including Nematopsis spp., cestodes, nematodes, ciliates and Rickettsiales-like organisms, but no haplosporidian was observed.

When the 220 base conserved region of Haplosporidium nelsoni SSU rDNA was aligned with that of Crassostrea virginica and $H$. costale, sequence similarities were 88.3 and $91.9 \%$, respectively. When the same region was put into a BLAST search, it had a high similarity value $(94.1 \%)$ to several species in the phylum Cercozoa, a sister phylum to Haplosporidia (Reece et al. 2004). 


\section{DISCUSSION}

Our results do not support the conclusion of Ulrich et al. (2007) that infections of Haplosporidium nelsoni are widespread among oysters in the Gulf of Mexico. Both our study and theirs sampled from some of the same sites (Fig. 1) and employed a PCR assay and primers designed to specifically amplify $H$. nelsoni. Both targeted the same region of the SSU rDNA. Our use of a slightly different forward primer would not have diminished the sensitivity of the assay. On the other hand, the 2 studies did differ in several important ways. The Ulrich et al. (2007) study did not include histological confirmation of the PCR results, whereas the negative results that we found in our PCR assay were consistent with those from histological examination of the same oysters, as well as previous histological surveys of Crassostrea virginica in the Gulf of Mexico, including the annual Mussel Watch analyses that began in 1995. Since at least 1978, several thousand oysters have been examined histologically without finding any recognizable haplosporidian (Couch 1985, Gauthier et al. 1990, Fisher et al. 1996, Kim et al. 1998, Fisher et al. 2000, Winstead et al. 2004, Kim \& Powell 2006). In addition, at least one other study has examined Gulf of Mexico oysters using both PCR and histology. A sample of 30 oysters from Grand Isle, Louisiana, USA, collected in November 2000, was negative for H. nelsoni by both assays (Russell et al. 2004).

The tissues analyzed were also different. We chose gill tissue, because it is most likely to harbor localized, early stage infections that may be missed using tissue sections that are only $5 \mu \mathrm{m}$ thick. Further, the gills, as organs of filtration and the initial site of infection, would be most likely to have externally adhering parasites that may not have established true infections (Ford et al. 2009). In contrast, Ulrich et al. (2007) used the adductor muscle, which means that any infections they detected would represent Haplosporidium nelsoni that had spread into the circulatory system and would be present in other tissues, as well as the gill. Systemic infections such as these are easier to detect both histologically and by PCR than localized gill infections, because the parasites are dispersed and more likely to be included in the tissues examined.

Most of our samples were collected during the winter months, whereas most of the Ulrich et al. (2007) collections were made in the summer. In enzootic locations along the mid-Atlantic and northeastern United States where seasonal infection patterns have been described, Haplosporidium nelsoni prevalence can be high in the summer, depending on when in the infection cycle oysters are collected, but infection prevalence and intensity are universally elevated in the winter (Andrews 1966, Ford \& Haskin 1982, Matthiessen et al. 1990). The southern-most location for which seasonal infection prevalence is available from histological analyses comes from the entrance to Charleston Harbor, South Carolina, USA, where sites were sampled in 1994 and 1995 (Bobo et al. 1997). At the site with the highest prevalence, infections predominated from fall into spring, and, at another site, they were more abundant in the fall and spring than in the winter or summer, but, when all sites were considered together, infections were found throughout the year. From the data available, therefore, there is no reason to think that with a sufficiently large sample size, true $H$. nelsoni infections would be missed by either PCR or histology at any time of the year.

Ulrich et al. (2007) were convinced that their results indicated real infections, and this would certainly be true considering the anatomical source of their tissue samples and assuming that their samples were not contaminated. Burreson (2008), however, has underscored the point that PCR detects DNA only and that PCR-positive results do not necessarily signal infections, especially when there have been no confirmatory visual observations in a new range such as the Gulf of Mexico would be for Haplosporidium nelsoni. On the other hand, it is conceivable that the parasite is present in the region, but not able to develop detectable infections or cause perceptible mortality. Ford et al. (2009) noted that $H$. nelsoni was observed in histological sections of oysters at several locations in New England, USA, many years before it caused epizootic mortalities. We agree with Ulrich et al. (2007) that the environment of the Gulf of Mexico should be favorable for $H$. nelsoni to survive, infect, and cause mortalities in the native oysters, which are highly susceptible when tested in enzootic regions (Ragone Calvo et al. 2003, Encomio et al. 2005). Perhaps the abundance of $H$. nelsoni in the gulf is too low to initiate an epizootic, as may have been the case in New England. Yet, in contrast to the New England experience, H. nelsoni has never been observed histologically in Gulf of Mexico oysters. Even if $H$. nelsoni were present in the gulf, but for some reason unable to develop infections, we might have expected to find some PCR-positive signals from gill samples, where the parasites may have lodged after being filtered from the water (Ford et al. 2009).

Ulrich et al. (2007) reported that their PCR reactions yielded multiple products, ranging from 288 to $543 \mathrm{bp}$, none of which was the expected size of $564 \mathrm{bp}$. When these products were sequenced, they had only 'a 215 bp region represented in clones from all oysters' (Ulrich et al. 2007, p. 196) and those clones had only $94.4 \%$ similarity when aligned with each other. These results may have been due to the permissive conditions used in their PCR assay. Ulrich et al. (2007) 
amended the reaction published by Stokes et al. (1995), increasing the $\mathrm{MgCl}_{2}$ concentration from 1.5 to $3.5 \mathrm{mM}$. They claimed that they increased stringency of the PCR by increasing the annealing temperature from 50 to $55^{\circ} \mathrm{C}$, which would be true if that were the only change made to the published protocol. By also greatly increasing the $\mathrm{MgCl}_{2}$ concentration, however, they may have negated the benefit of annealing at $55^{\circ} \mathrm{C}$ and actually decreased PCR stringency, thus losing the assay's specificity and possibly allowing amplification of non-Haplosporidium nelsoni DNA.

The $\sim 220$ base sequence of the conserved region of Haplosporidium nelsoni SSU rDNA is about the same size as that used in the phylogenetic trees produced by Ulrich et al. (2007). A BLAST search revealed that this sequence has a $94.1 \%$ similarity to that of several members of the phylum Cercozoa, a sister phylum to Haplosporidia (Reece et al. 2004). Thus, it is very possible that the sequence thought by Ulrich et al. (2007) to belong to $H$. nelsoni was actually a conserved region of SSU rDNA from another organism or organisms related to $H$. nelsoni. Unfortunately, their paper did not include any gel images, and sequence data were not deposited into GenBank, so it is impossible to make independent judgments about their sequence results.

In conclusion, we are unable to confirm the finding of Haplosporidium nelsoni in oysters from around the Gulf of Mexico and Puerto Rico. As discussed above, Ulrich et al. (2007) may have detected DNA from one or more organisms other than H. nelsoni; however, if $H$. nelsoni-infected oysters are truly as abundant $(73 \%)$ and widespread as claimed by these authors, it is surprising that we found no PCR evidence of the parasite given our substantially larger sample size (210 vs. 41 oysters) and more intensive geographic coverage ( 40 vs. 4 sites around the Gulf of Mexico and Puerto Rico). Additionally, $>30 \mathrm{yr}$ of studies and monitoring involving histological examination of gulf oysters have failed to detect any haplosporidian infections. Our results are important, not only from the point of view of what physical or biological mechanisms might be preventing $H$. nelsoni from existing or becoming prevalent in the Gulf of Mexico, or at least from developing infections in oysters there, but also from a very practical perspective. If the pathogen is present in the gulf, arguments against importing oysters from enzootic regions have less weight than they do if it is not present. Our results do not prove that $H$. nelsoni is absent from the Gulf of Mexico and the Caribbean Sea. Nevertheless, they, along with those from previous histological surveys, suggest that, for the purposes of controlling oyster importation and minimizing the chances for introduction, the region should continue to be considered free of the parasite.
Acknowledgements. We thank Kurt Cheng and Iris Burt for help processing oysters; Ximing Guo for DNA-assay advice; and the field team at TDI-Brooks International, as well as Graham Lewis and his staff at the Northwest Florida Water Management District for collecting and shipping oysters. Partial financial support was provided by the NOAA through its National Status and Trends Program. This is VIMS Contribution Number 3141.

\section{LITERATURE CITED}

Altschul SF, Madden TL, Schaffer AA, Zhang JH, Zhang Z, Miller W, Lipman DJ (1997) Gapped BLAST and PSIBLAST: a new generation of protein database search programs. Nucleic Acids Res 25:3389-3402

Andrews JD (1966) Oyster mortality studies in Virginia. V. Epizootiology of MSX, a protistan parasite of oysters. Ecology 47:19-31

Barber BJ, Langan R, Howell TL (1997) Haplosporidium nelsoni (MSX) epizootic in the Piscataqua River estuary (Maine-New Hampshire, USA). J Parasitol 83:148-150

Bobo MY, Richardson DL, Coen LD, Burrell VG (1997) A report on the protozoan pathogens Perkinsus marinus (Dermo) and Haplosporidium nelsoni (MSX) in South Carolina shellfish populations. Report No. 86, South Carolina Department of Natural Resources, Charleston, SC

Burreson EM (2008) Misuse of PCR assay for diagnosis of mollusc protistan infections. Dis Aquat Org 80:81-83

$>$ Couch JA (1985) Prospective study of infectious and noninfectious diseases in oysters and fishes in three Gulf of Mexico estuaries. Dis Aquat Org 1:59-82

Encomio VG, Stickler SM, Allen SK, Chu FL (2005) Performance of 'natural dermo-resistant' oyster stocks-survival, disease, growth, condition and energy reserves. J Shellfish Res 24:143-155

Fisher WS, Winstead JT, Oliver LM, Edmiston HL, Bailey GO (1996) Physiologic variability of eastern oysters from Apalachicola Bay, Florida. J Shellfish Res 15:543-553

Fisher WS, Oliver LM, Winstead JT, Long ER (2000) A survey of oysters Crassostrea virginica from Tampa Bay, Florida: associations of internal defense measurements with contaminant burdens. Aquat Toxicol 51:115-138

Ford SE, Haskin HH (1982) History and epizootiology of Haplosporidium nelsoni (MSX), an oyster pathogen, in Delaware Bay, 1957-1980. J Invertebr Pathol 40:118-141

Ford SE, Allam B, Xu Z (2009) Using bivalves as particle collectors and PCR detection to investigate the environmental distribution of Haplosporidium nelsoni. Dis Aquat Org 83:159-168

Gauthier JD, Soniat TM, Rogers JS (1990) A parasitological survey of oysters along salinity gradients in coastal Louisiana. J World Aquacult Soc 21:105-115

Haskin HH, Andrews JD (1988) Uncertainties and speculations about the life cycle of the eastern oyster pathogen Haplosporidium nelsoni (MSX). In: Fisher WS (ed) Disease processes in marine bivalve molluscs, Vol 18. American Fisheries Society, Bethesda, MD, p 5-22

Kim Y, Powell EN (2006) Relationships among parasites and pathologies in sentinel bivalves: NOAA status and trends 'Mussel Watch' program. Bull Mar Sci 79:83-111

Kim Y, Powell EN (2007) Distribution of parasites and pathologies in sentinel bivalves: NOAA status and trends 'Mussel Watch' program. J Shellfish Res 26:1115-1151

Kim Y, Powell EN, Wade TL, Presley BJ, Sericano J (1998) Parasites of sentinel bivalves in the NOAA status and trends program: distribution and relationship to contaminant body burden. Mar Pollut Bull 37:45-55 
Matthiessen GC, Feng SY, Leibovitz L (1990) Patterns of MSX (Haplosporidium nelsoni) infection and subsequent mortality in resistant and susceptible strains of the eastern oyster Crassostrea virginica (Gmelin, 1791) in New England. J Shellfish Res 9:359-366

Ragone Calvo LM, Calvo GW, Burreson EM (2003) Dual disease resistance in a selectively bred eastern oyster, Crassostrea virginica, strain tested in Chesapeake Bay. Aquaculture 220:69-87

Reece KS, Siddall ME, Stokes NA, Burreson EM (2004) Molecular phylogeny of the Haplosporidia based on two independent gene sequences. J Parasitol 90:1111-1122

Renault T, Stokes NA, Chollet B, Cochennec N, Berthe F, Gerard A, Burreson EM (2000) Haplosporidiosis in the Pacific oyster Crassostrea gigas from the French Atlantic coast. Dis Aquat Org 42:207-214

Russell S, Frasca S, Sunila I, French RA (2004) Application of

Editorial responsibility: Eugene Burreson,

Gloucester Point, Virginia, USA a multiplex PCR for the detection of protozoan pathogens of the eastern oyster Crassostrea virginica in field samples. Dis Aquat Org 59:85-91

Stephenson MF, McGladdery SE, Maillet M, Veniot A, Meyer G (2003) First reported occurrence of MSX in Canada. J Shellfish Res 22:355

Stokes NA, Siddall ME, Burreson EM (1995) Detection of Haplosporidium nelsoni (Haplosporidia, Haplosporidiidae) in oysters by PCR amplification. Dis Aquat Org 23:145-152

Ulrich PN, Colton CM, Hoover CA, Gaffney PM, Marsh AG (2007) Haplosporidium nelsoni (MSX) rDNA detected in oysters from the Gulf of Mexico and the Caribbean Sea. J Shellfish Res 26:195-199

Winstead JT, Volety AK, Tolley SG (2004) Parasitic and symbiotic fauna in oysters (Crassostrea virginica) collected from the Caloosahatchee River and Estuary in Florida. J Shellfish Res 23:831-840

Submitted: August 16, 2010; Accepted: November 1, 2010 Proofs received from author(s): February 14, 2011 